\title{
Planar complexation chromatography of transition metal ions
}

\author{
Krasikov V.D. ${ }^{1}$, Malakhova I.I. ${ }^{1}$, Gorshkov N.I. ${ }^{1}$, \\ Belyaev A.N. ${ }^{2}$, Staroverov S.M. ${ }^{3}$ \\ ${ }^{I}$ Federal State Budgetary Institution of Science Institute of Macromolecular Compounds of Russian Academy \\ of Sciences, Saint-Petersburg \\ ${ }^{2}$ Saint-Petersburg State Technological Institute (Technical University), Saint-Petersburg \\ ${ }^{3}$ Department of Chemistry, M.V.Lomonosov Moscow State University, Moscow
}

Received 25.04.2017

The method for analysis of transition metal ions ( $\mathrm{Zn}(\mathrm{II}), \mathrm{Cu}(\mathrm{II}), \mathrm{Co}(\mathrm{II}), \mathrm{Ni}(\mathrm{II}), \mathrm{Fe}(\mathrm{III})$ ) by highperformance planar (thin layer) chromatography with the use of sorbents modified by chelating fragments of iminodiacetic acid was developed. The correlation between retention factor $(R f)$ and physico-chemical parameters of the separated systems was studied. It was demonstrated that unlike the $\mathrm{pH}$ value, ionic strength of a solution does not exert significant influence on resolution and mobility of transition metal cations.

Keywords: thin layer chromatography, modified silica gels, chelate agents, iminodiacetic acid, transition metals.

\section{Планарная комплексообразующая хроматография ионов переходных металлов}

\author{
Красиков В.Д. ${ }^{1}$, Малахова И.И. ${ }^{1}$, Горшков Н.И. ${ }^{1}$, \\ Беляев А.Н. ${ }^{2}$, Староверов С.M. ${ }^{3}$ \\ ${ }^{I}$ Федеральное государственное бюджетное учреждение науки Институт высокомолекулярных со- \\ единений Российской Академии наук, Санкт-Петербург \\ ${ }^{2}$ санкт-Петербургский государственный технологический институт (Технический Университет), \\ Санкт-Петербург \\ ${ }^{3}$ Московский государственный университет им. М.В. Ломоносова, Москва
}

Разработан метод анализа ионов переходных металлов (Zn(II), Cu(II), Co(II), Ni(II), $\mathrm{Fe}(\mathrm{III}))$ на основе высокоэффективной плоскостной (тонкослойной) хроматографии с использованием сорбентов, модифицированных хелатными фрагментами иминодиуксусной кислоты. Изучена корреляция между фактором удерживания $\left(\mathrm{R}_{\mathrm{f}}\right)$ и физико-химическими параметрами разделенных систем. Показано, что в отличие от $\mathrm{pH}$, ионная сила раствора не оказывает существенного влияния на разрешение и подвижность катионов переходныхметаллов.

Ключевые слова: тонкослойная хроматография, модифицированные силикагели, хелатные агенты, иминодиуксусная кислота, переходные металлы.

\section{Introduction}

Transition metals (cobalt, copper, zinc and manganese) are trace elements which are necessary for vital activity of human organism. A number of transition metals are coenzymes for more than 70 enzymes of organism; they participate in the formation of vitamins, hormones, and regulation of metabolism. Even insignificant variations in the lev- 
el of these microelements in blood cause serious diseases. Dramatic change in concentrations of biometals in blood may serve as precursory symptoms of malignant transformation of cells. Thus, decrease in zinc level in blood is a result of cardiac infarction, and changes in zinc level in sperm and urine can be indicative of prostate cancer [1].

Spectrometric [2] and chemical chromophore methods [3] are widely used in quantitative analysis of microelements. The latter methods are remarkable by simplicity, high sensitivity and specificity in analysis of microelements. Among the most important physico-chemical methods in analysis of biogenic metals is high performance liquid chromatography (HPLC), namely, its two variants, ionic chromatography (IC) [4] and thin layer chromatography (TLC) [5].

The authors of [6] discussed possible use of high-performance thin layer chromatography (HPTLC) on native silica gels and silica gels modified by amino phase in the analysis of a number of microelements. However, there is little information about highperformance complexation chromatography of metal ions (HPCCI) [7] which opens up new possibilities in analysis of ions.

There are data on sorption properties of silica gel with grafted iminodiacetic acid (IDAA) in the literature [8,9]. However, these data refer to the sorbents which are not used as TLC phases, and to another chromatographic regime. Therefore, it is appropriate to study peculiarities of sorption of metal ions within concrete static (drop) and dynamic models of chelate TLC.

The aim of the work is to study possible use of chromatographic phases modified with iminodiacetic acid in planar high-performance complexation chromatography of a number of biometal ions ( $\mathrm{Zn}(\mathrm{II}), \mathrm{Cu}(\mathrm{II}), \mathrm{Co}(\mathrm{II}), \mathrm{Ni}(\mathrm{II})$ и $\mathrm{Fe}(\mathrm{III})$ ).

\section{Experimental}

The used reagents were of puriss. or puriss. spec. grade, and were purchased from «Sigma-Aldrich» (USA), «Vekton» (Russia) and «Neva-Reaktiv» (Russia). Aqueous solutions were prepared with the use of water deionized by the mixture of ion-exchange resins (KU-2, AV-17, 1:1).

Silica gel KSK-G (specific surface $250 \mathrm{~m}^{2} / \mathrm{g}$, average pore diameter $13 \mathrm{~nm}$ ) was used as a sorbent for planar chromatography.

TLC experiments were performed using protonated silica gel plates (Sorbfil PTSHP-A, Russia) modified with iminodiacetic acid (Sorbfil PTSH-P-A-IDAA).

Protonation of thin layer silica gel plates was performed by submerging plates into $6 \mathrm{~N} \mathrm{HCl}$ solution for $15 \mathrm{~min}$. After treatment, the plates were washed with distilled water and dried in desiccator for $45 \mathrm{~min}$ at $120^{\circ} \mathrm{C}$.

Silica gels chemically modified with chelating agents were prepared by the immobilization method. Ligand was immobilized on silica gel surface in two stages, and organosilicon modifier was obtained. The first stage involved epoxy-activated compounds with terminal reactive epoxy groups which easily react with organic molecules containing mobile secondary or tertiary amino groups. Organosilicon modifier for preparation of TLC plates with immobilized IDAA as a chelating agent was obtained as follows: $0.1 \%$ aqueous solution of iminodiacetic acid $(0.075 \mathrm{~mol})$ was neutralized with $5 \mathrm{M}$ solution of sodium hydroxide until the $\mathrm{pH}$ value of 10.5 was reached. Then, 3-glycidoxypropyltrimethoxysilane (ES-1) $(18.3 \mathrm{~mL}, 0.067 \mathrm{~mol})$ was added, and the mixture was heated at stirring at $90-100^{\circ} \mathrm{C}$ for $40-60$ min until ES-1 was fully dissolved. The obtained solution $(\mathrm{pH}=11-12)$ was cooled down to $25^{\circ} \mathrm{C}$ and neutralized with glacial acetic acid until the $\mathrm{pH}$ value of 5.6-5.9 was achieved. Then the mixture was diluted twofold with water, and 
sodium chloride was added in order to reach the total ionic strength of $0.5-0.1$. The preparation of organosilicon modifier can be schematically presented in the following way:

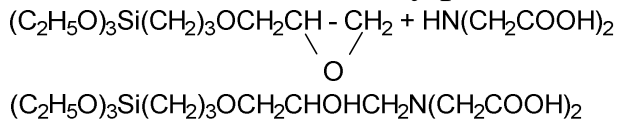

Silica gel matrix of TLC plates was transformed into cation exchanger with functional groups of iminodiacetic acid in the following manner: TLC plates were heated in the solution of the modifier at $90-100^{\circ} \mathrm{C}$ for $3 \mathrm{hrs}$ with subsequent washing of plate surface by distilled water, $1 \mathrm{M}$ solution of sulfuric acid; then the plates were washed with water for the second time. Finally, TLC plates were dried while the temperature was gradually increased from 25 to $120^{\circ} \mathrm{C}$. Immobilization of silica gel matrix of the TLC plates can be presented as follows:

$$
\begin{aligned}
& \left.\mathrm{SiO}_{2}\right)-\mathrm{OH}+\left(\mathrm{C}_{2} \mathrm{H}_{5} \mathrm{O}\right)_{3} \mathrm{Si}\left(\mathrm{CH}_{2}\right)_{3} \mathrm{OCH}_{2} \mathrm{CHOHCH}_{2} \mathrm{~N}\left(\mathrm{CH}_{2} \mathrm{COOH}\right)_{2} \longrightarrow \\
& \left.\mathrm{SiO}_{2}\right)-\mathrm{O}-\left(\mathrm{C}_{2} \mathrm{H}_{5} \mathrm{O}\right)_{2} \mathrm{Si}\left(\mathrm{CH}_{2}\right)_{3} \mathrm{OCH}_{2} \mathrm{CHOHCH}_{2} \mathrm{~N}\left(\mathrm{CH}_{2} \mathrm{COOH}\right)_{2}+\mathrm{C}_{2} \mathrm{H}_{5} \mathrm{OH}
\end{aligned}
$$

TLC plates modified with grafted cation-exchanger and its dissociation are presented in the following scheme:

$$
-\mathrm{N}^{-}=\mathrm{CH}_{2} \mathrm{COOH} \longrightarrow-\mathrm{NH}^{+}=\mathrm{CH}_{2} \mathrm{COOO}_{2}^{-}
$$

Ions were detected with the use of a chromophore complexonate (dithizone, $\mathrm{C}_{13} \mathrm{H}_{12} \mathrm{~N}_{4} \mathrm{~S}$, puriss.)

Quantitative analysis of chromatograms was performed using a "DenScan" videodensitometer (Lenchrom, Russia) in the visible spectral region with different optical filters. The obtained data were processed with the use of "Dens" (Lenchrom, Russia) and "Multichrom-TLC" software (Lenchrom-Ampersand, Russia).

The following transition metal ions were chosen as objects: $\mathrm{Ni}(\mathrm{II}), \mathrm{Co}(\mathrm{II}), \mathrm{Cu}(\mathrm{II})$, $\mathrm{Zn}(\mathrm{II}), \mathrm{Fe}(\mathrm{III})$ in the form of nitrates, sulfates and chlorides (p.a. grade).

\section{Results and discussion}

Separation of metals was based on the ability of chelating cation exchangers to form kinetically labile surface complexes with ions. In comparison with the common ionexchange chromatography, high-performance complexation chromatography of metal ions demonstrates additional selectivity in separation of bivalent and trivalent metal cations [10].

In order to prevent hydrolysis of metal ions and selective desorption of metal cations, it is necessary to carry out separation in acidic media $(\mathrm{pH}<3)$ [11]. Iminodiacetic acid (IDAA) was chosen as a chelating agent on the basis of the literature data on HPCCI; the literature data indicate high stability of the silica gel sorbent modified by this ligand in strongly acidic solutions [12-13]. IDAA forms stable complexes with transition metal ions over a wide acidity interval [14]. Unlike weakly and strongly acidic cation exchangers, this sorbent is characterized by less significant dependence between sorption and ionic strength of solution and the presence of $\mathrm{Ca}$ (II) and $\mathrm{Mg}$ (II) ions in a sample [15]. Stability of complexes is related to the fact that carbonyl groups of IDAA form a stable three dentate chelating site (fig. 1).

It was established that sorption of the studied metal ions proceeds in a wide acidity interval. For example, in neutral and weakly acidic regions, complete sorption of metal ions is observed. Differences in dependences of sorption of different cations on $\mathrm{pH}$ of a solution allow for separation of a number of ions by planar chromatography (see fig. 2). 


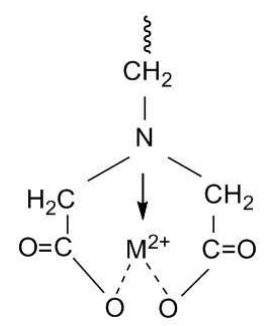

Fig. 1. Interaction between grafted IDAA fragments and a bivalent metal cation.

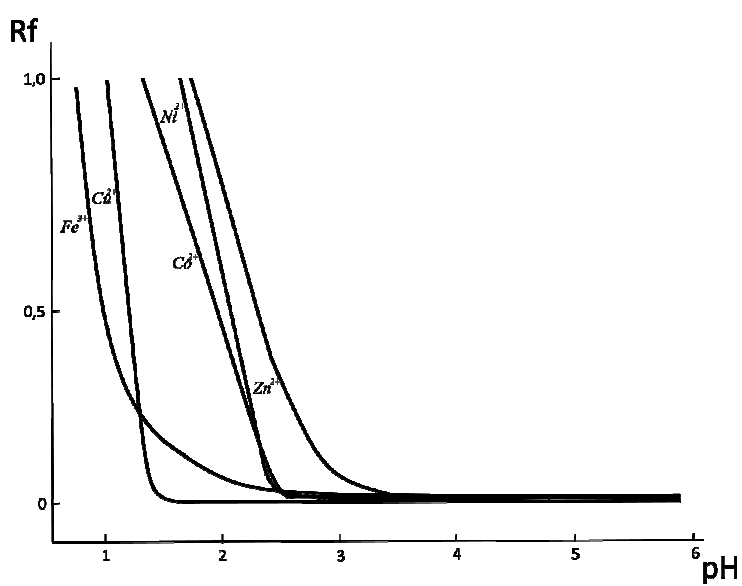

Fig. 2. Sorption curves of $\mathrm{Cu}(\mathrm{II}), \mathrm{Fe}(\mathrm{III}), \mathrm{Zn}(\mathrm{II}), \mathrm{Co}(\mathrm{II}), \mathrm{Ni}(\mathrm{II})$ ions on TLC plates modified by IDAA.

Optimization of the eluting system with respect to acidity is related to the fact that decrease in $\mathrm{pH}$ leads to protonation of functional groups of the bidentate ligand and decrease in effective concentration of reactive forms of the immobilized ligands; therefore, mobility $(R f)$ of the separated cations increases. Mobile phase $(0.2 \mathrm{M}$ solution of hydrochloric acid with added $\mathrm{NaNO}_{3}(\mathrm{C}=0.2 \mathrm{M})$ ) provides reliable separation of the analyzed ions (Co(II), Ni(II), $\mathrm{Cu}(\mathrm{II}), \mathrm{Zn}(\mathrm{II})$ and $\mathrm{Fe}(\mathrm{III}))$. Fig. 3 presents the results of chromatographic analysis.

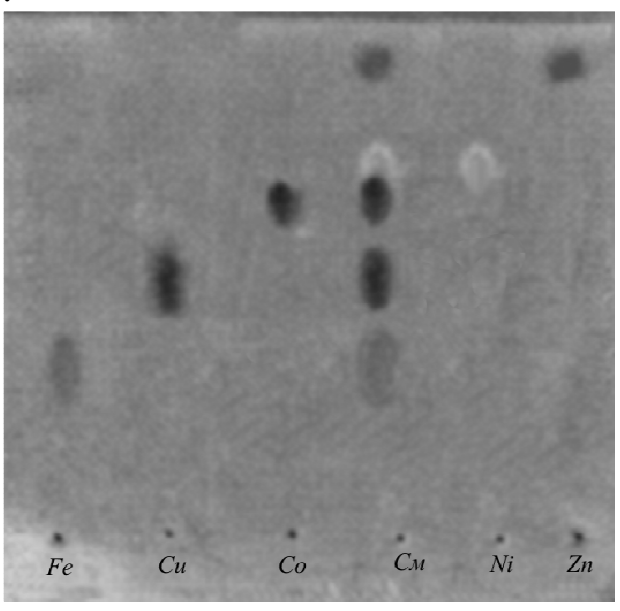

a

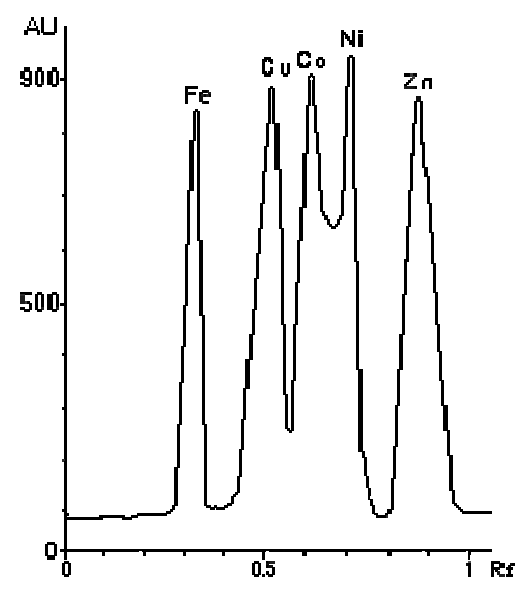

6

Fig. 3. a) Thin layer chromatogram of $\mathrm{Fe}(\mathrm{III}) \mathrm{Cu}(\mathrm{II}), \mathrm{Co}(\mathrm{II}), \mathrm{Ni}(\mathrm{II}), \mathrm{Zn}(\mathrm{II})$ and separation of the mixture of these cations; b) Densitogram of separation of the mixture of

$\mathrm{Fe}(\mathrm{III}) \mathrm{Cu}(\mathrm{II}), \mathrm{Co}(\mathrm{II}), \mathrm{Ni}(\mathrm{II}), \mathrm{Zn}$ (II). TLC plate: PTLC-P-A-IDAA; eluent: $0.2 \mathrm{M}$ $\mathrm{HCl}+0.2 \mathrm{M} \mathrm{NaNO}_{3}(9: 1)$; detection: $0.1 \%$ solution of dithizone in $\mathrm{CCl}_{4} ; \mathrm{pH}=0.7$. 
Comparison between the data obtained with the use of the plates with immobilized IDAA and the data on separation of the same ions on native silica gel is presented in Tables 1 and 2 .

Calculation of separation selectivity $(\alpha)$ on these two sorbents demonstrated that in both cases, the values are virtually the same; however, this result does not indicate good separation of components. Separation of two components is characterized by the resolution factor $\left(R_{S}\right)$, and this parameter depends on lengthwise blurring of stains during chromatography. In the case of native silica gel, blurring of zones is more pronounced due to residual sorption of cations, which cannot be completely excluded. As a result, we obtain stains with the so-called "tails", this leading to dramatic decrease in the values of separation degree $\mathrm{R}_{\mathrm{S}}$ (Table 2).

Table 1. Mobility of metal ions on silica sorbents and the sorbents with grafted chelating groups

\begin{tabular}{|c|c|c|c|c|c|}
\hline TLC sorbent & \multicolumn{5}{|c|}{$\mathrm{The}_{\mathrm{f}} \mathrm{values}$} \\
\cline { 2 - 6 } & $\mathrm{Zn}^{2+}$ & $\mathrm{Cu}^{2+}$ & $\mathrm{Co}^{2+}$ & $\mathrm{Ni}^{2+}$ & $\mathrm{Fe}^{3+}$ \\
\hline $\begin{array}{c}\text { Silica gel, } \\
\text { Ethanol - Acetone - Acetic acid (4-5-2) }\end{array}$ & 0.37 & 0.73 & 5 & 0.57 & 0.94 \\
\hline $\begin{array}{c}\text { Silica gel modified by IDAA } \\
\text { O.2 M HCl+0.2M NaNO}\end{array}$ (9:1) & 0.91 & 0.5 & 0.6 & 0.72 & 0.3 \\
\hline
\end{tabular}

Table 2. Chromatographic parameters of separation

\begin{tabular}{|c|c|c|c|c|c|}
\hline \multicolumn{2}{|c|}{ Silica gel modified by IDAA } & \multicolumn{3}{c|}{ Silica gel, } \\
$0.2 \mathrm{M} \mathrm{HCl}-0.2 \mathrm{M} \mathrm{NaNO}(9: 1)$ & \multicolumn{2}{c|}{ Ethanol - Acetone - Acetic acid $(4: 5: 2)$} \\
\hline Cation pairs & $\alpha$ & $\mathrm{R}_{\mathrm{S}}$ & Cation pairs & $\alpha$ & $\mathrm{R}_{\mathrm{S}}$ \\
\hline $\mathrm{Fe}^{3+} / \mathrm{Cu}^{2+}$ & $1.66 \pm 0.04$ & $1.5 \pm 0.04$ & $\mathrm{Zn}^{2+} / \mathrm{Co}^{2+}$ & $1.35 \pm 0.05$ & $0.94 \pm 0.02$ \\
\hline $\mathrm{Cu}^{2+} / \mathrm{Co}^{2+}$ & $1.2 \pm 0.02$ & $2.0 \pm 0.04$ & $\mathrm{Co}^{2+} / \mathrm{Ni}^{2+}$ & $1.14 \pm 0.03$ & $0.34 \pm 0.04$ \\
\hline $\mathrm{Co}^{2+} / \mathrm{Ni}^{2+}$ & $1.2 \pm 0.03$ & $1.8 \pm 0.03$ & $\mathrm{Ni}^{2+} / \mathrm{Cu}^{2+}$ & $1.28 \pm 0.03$ & $1.16 \pm 0.01$ \\
\hline $\mathrm{Ni}^{2+} / \mathrm{Zn}^{2+}$ & $1.26 \pm 0.03$ & $6.2 \pm 0.15$ & $\mathrm{Cu}^{2+} / \mathrm{Fe}^{3+}$ & $1.28 \pm 0.04$ & $1.8 \pm 0.04$ \\
\hline
\end{tabular}

The presence of chelating agent (IDAA) on silica gel surface of a TLC plate does not indicate that donor-acceptor interactions become the prevailing forces in retention of metal ions. Negatively charged carboxyl groups may retain positively charged ions due to electrostatic interactions. In order to diminish or remove this effect completely, strong electrolytes $\left(\mathrm{NaNO}_{3}, \mathrm{NaCl}\right)$ are added to eluent; counterions form a shielding layer around negatively charged functional groups and prevent (or significantly diminish) electrostatic interactions with cations. However, this effect (suppressing electrostatic interactions) is pronounced in the case of alkali-earth metals or lanthanides [15], but is not significant for transition metal ions (Mg(II), $\mathrm{Co}(\mathrm{II}), \mathrm{Cd}(\mathrm{II}), \mathrm{Zn}(\mathrm{II}), \mathrm{Ni}(\mathrm{II}), \mathrm{Cu}(\mathrm{II})$ ) on IDAA-modified silica gel. In the latter case, surface complexation prevails, and the values of complexation constants between transition metals and IDAA $\left(\operatorname{Lg} \beta_{1} \sim 4.72-10.56\right)$ are much higher than those for the corresponding complexes of alkali-earth metals $\left(\operatorname{Lg} \beta_{1} \sim 1.67-2.98\right)$ [16].

The studies of this effect by TLC analysis with the use of IDAA-modified silica gel and with adding electrolyte (sodium nitrate) into eluent demonstrated that changes in salt concentration in dithizone (from 0.2 to $0.8 \mathrm{M}$ ) did not exert significant influence on elution order and resolution of the studied cations.

Chromatographic properties and maximum total capacitance of chelating ion exchangers depend on the density and distribution of immobilized functional groups. It is known that due to steric hindrances, only about $50 \%$ of silanol groups on silica surface can react with silanes [17]. It is necessary to transform silica gel into "acidic" form in order to 
reach the maximum amount of silanol groups on silica gel surface and, therefore, to increase cation exchanger capacity in the process of sorbent modification.

Concentration of silanol groups on the surface of protonated silica gel is 4.6-4.8 groups per $1 \mathrm{~nm}^{2}$. Thus, calculated density of grafting to silane is 0.91 molecules of IDAA per $1 \mathrm{~nm}^{2}$ of surface. It was established that the maximum total capacitance of the $\mathrm{SiO}_{2}$ IDAA sorbent is about $12 \mathrm{mg} / \mathrm{g}$. This value agrees well with the literature data on the average amount of IDAA fragments grafted onto KSKG silica gel $\left(D_{\text {pore }}=15 \mathrm{~nm}, V_{\text {pore }}=\right.$ $0.9 \mathrm{~mL} / \mathrm{g}, S=230 \mathrm{mg} / \mathrm{g}$ ); this amount allows for reaching effective capacitance for this type of sorbent (e.g. $0.56 \mathrm{mg} \mathrm{eq} / \mathrm{m}^{2}$ or $0.13 \mathrm{mg}$ eq/g for $\mathrm{Zn}$ (II)) [18]. The experimental data show that at the maximum load, the TLC sorbent allows performing group quantitative densitometric analysis of no less than 5-6 target analytes.

In individual chromophore and/or spectrophotometric determination of ions in a group, it is necessary to choose selective chromophore organic reactants which participate in color or luminescent reactions. Currently, there are more than 300 complexons for analysis of different groups of ions [3]. The studies demonstrate that dithizone is the best reactant for group analysis of microelements (transition metal ions); this is a universal dye with sufficiently high sensibility for determination of all analyzed cations. Sensibilities of all other reactants in thin layer chromatography were an order of magnitude lower than dithizone sensibility; some of these compounds can be used only as specific reactants.

Chromophore reactions between transition metals and dithizone dissolved in $\mathrm{CCl}_{4}$ cause different coloration of ions: red $\left(\mathrm{Zn}^{2+}, \mathrm{Fe}^{3+}\right)$, light green $\left(\mathrm{Cu}^{2+}\right)$, dark violet $\left(\mathrm{Co}^{2+}\right)$, green $\left(\mathrm{Ni}^{2+}\right)$. In a number of experiments, detection limit of $\mathrm{Zn}, \mathrm{Cu}, \mathrm{Co}, \mathrm{Fe}$ and $\mathrm{Ni}$ ions in the static drop chromatography regime was determined (Fig. 4).

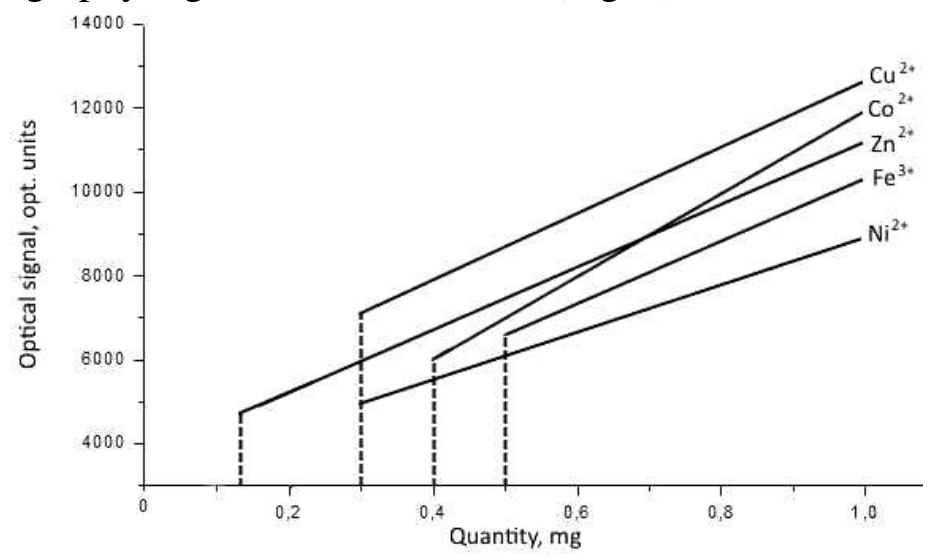

Fig. 4. Calibration curves for a group of cations in drop chromatography regime (detection with $0.1 \%$ solution of dithizone in carbon tetrachloride).

Sensitivity values of drop reactions on modified silica gel plates to $\mathrm{Co}(\mathrm{II}), \mathrm{Ni}(\mathrm{II})$, $\mathrm{Cu}(\mathrm{II}), \mathrm{Zn}(\mathrm{II}), \mathrm{Fe}(\mathrm{III})$ were equal to $0.4,0.3,0.3,0.125$ and $0.5 \mu \mathrm{g}$, respectively.

\section{Conclusions}

The proposed method of planar analysis on silica gel plates modified with iminodiacetic acid allows reliable determination of a number of transition metal cations. Sensibility values of dynamic and drop methods of analysis of $\mathrm{Zn}(\mathrm{II}), \mathrm{Cu}(\mathrm{II}), \mathrm{Co}$ (II), $\mathrm{Ni}$ (II), $\mathrm{Fe}(\mathrm{III})$ ions were determined and were equal to $0.125,0.3,0.4,0.3$ and $0.5 \mu \mathrm{g}$ in chromatographic zone.

It was established that separation of the studied transition metal cations by high performance thin layer chromatography on silica gel sorbents modified with IDAA strong- 
ly depends on $\mathrm{pH}$ of an eluent and virtually does not depend on ionic strength of solution. Efficiency of ion separation on IDAA-modified plates exceeds the efficiency of native silica gel sorbents.

\section{References}

1. Costello L.C., Franklin R.B., Molecular Cancer, 2006, Vol. 5, No 17, pp. 1-13.

2. Pupishev A.A., Atomno-absorbtsionnii spektralnii analyz. M., Tehnosphera, 2009, 784 p.

3. ZolotovYu. A., Ivanov V. M., AmelinV.G., Himicheskie test-metodi analiza. M.: Editirial URSS, 2002. 304 p.

4. Fritz J.S., Gjerde D.T. Ion Chromatography, Wiley-VCH Verlag, Weinheim, 2009, 385 p.

5. Volinets M.P., Kolichstvennaya tonkosloinaya hromatographiya $\mathrm{v}$ neorganichskom analyze . M., Nauka, 1993. 240 p.

6. Malakhova I.I., Belyaev A.N., Krasikov V.D., Sorbtsionnye $i$ khromatograficheskie protsessy, 2015, Vol. 15, No 6, pp. 802-810.

7. Nesterenko P.N., Djons F., Poll B., M. Tehnosphera, 2013, 312 p..

8. Herring R., Helatoobrazuyschie ionoobmenniki,. M., Mir, 1971, 280 p.

9. Myasoedova G.B., Savvin S.B., Helatoobrazuyschie sorbenti, M., Himiya, 1984, 171 p.

10. Jones P., Challenger O.J., Hill S.J. Recent advances in high-performance chelation ion chromatography for trace-metal determinations, in Ion Exchange Processes: Advances and Applications, ed. A. Dyer, M.J. Hudson, P.A. Williams, Royal

Красиков Валерий Дмитриевич - зав. аналитической лабораторией, д.х.н., Федеральное государственное бюджетное учреждение науки Институт высокомолекулярных соединений Российской академии наук, Санкт-Петербур

Малахова Ирина Ивановна - старший научный сотрудник аналитической лаборатории, к.х.н., Федеральное государственное бюджетное учреждение науки Институт высокомолекулярных соединений Российской академии наук, Санкт-Петербург

Горшков Николай Иванович - старший научный сотрудник аналитической лаборатории, к.Х.н., Федеральное государственное бюджетное учреждение науки Институт высокомолекулярных соединений Российской академии наук, Санкт-Петербург

Беляев Александр Николаевич - профессор, д.х.н., Федеральное государственное бюджетное образовательное учреждение высшего профессионального образования "Санкт-Петербургский государственный технологический институт (технический университет)", Санкт-Петербур

Староверов Сергей Михайлович - заведующий лабораторией «Новые химические технологии для медицины», д.х.н., кафедра химической энзимологии Химического факультета МГУ им. М. В. Ломоносова, Москва
Society of Chemistry, Cambridge, 1993, pp.279287.

11. Frits Dj., GierdeD., Poland K. Ionnayahromatographya, M., Mir, 1984, 221 p.

12. Bonn G.K., Nathakarnkitkool S., Jandik P., Coordination chromatography of transition metals: efficient and selective separations of cations on iminodiacetate functional groups, in Advances in Ion Chromatography, ed. P. Jandik and R.M. Cassidy, Century International, Medfield, MA, 1991, pp. 197-214.

13.Jones P., Nesterenko P.N., Chelation ion chromatography, in Encyclopedia of Analytical Science, ed. P.J. Worsfold, A. Townsend and C.E. Poole, Academic Press, Amsterdam, 2004, pp. 467-480.

14. Tria J., Haddad P.R., Nesterenko P.N., J. Separation Science, 2008, Vol. 31, pp. 2231-2238.

15. Bashir W., Paull B., J. Chromatogr A, 2001, Vol. 907, pp. 191-200.

16. Nesterenko P.N., Jones P., J. Chromatogr. A, 1988, Vol. 804, pp. 223-231.

17. Ailer R.K. Himiya kremnezema. M., Mir. 1982, Vol. 1,2. 712 p.

18. Busche B., Wiacek R., Davidson J., Koonsiripaiboon V. et al., Chem. Commun. 2009, Vol. 12, pp. 312-315.

Krasikov Valerii D. - head of analytical laboratory, Dr.Sc.Chem, Institute of Macromolecular Compounds Russian Academy of Sciences, Saint-Petersburg, lenchrom@hq.macro.ru

Malakhova Irina I. - senior researcher, $\mathrm{PhD}$, (chemistry), analytical laboratory, Institute of Macromolecular Compounds Russian Academy of Sciences, SaintPetersburg, $\underline{\text { iimalahova@mail.ru }}$

Gorshkov Nikolay I. - senior researcher, $\mathrm{PhD}$, (chemistry), analytical laboratory, Institute of Macromolecular Compounds Russian Academy of Sciences, SaintPetersburg, ngorshkov@mail.ru

Belyaev Alexander N. - Professor, Dr.Sc.Chem, Federal State Educational Institution of Higher Professional Education "Saint-Petersburg State Technological Institute (Technical University)," St. Petersburg, anbelyaev@ gmail.com

Staroverov Sergey M. - Dr.Sc.Chem, Head of lab «Novel chemical technologies for medicine» Department of Chemical Enzymology, Chemical Faculty, Moscow State University. M. V. Lomonosov, Moscow, staroverov@bcmst.ru 